\title{
Online Dispute Resolution as an Alternative Settlement Against the Protection of Consumer Privacy Data in E-commerce Platform
}

\author{
Rahandy Rizki Prananda ${ }^{1}$, Ro' fah Setyowati ${ }^{2}$, Hendro Saptono ${ }^{3}$, Aista Wisnu Putra ${ }^{4}$ \\ \{rahandyrizkiprananda@lecturer.undip.ac.id ${ }^{1}$, rofahsetyowati@lecturer.undip.ac.id ${ }^{2}$, \\ hendrosaptono@lecturer.undip.ac.id ${ }^{3}$, aistawisnuputra@students.undip.ac.id $\left.{ }^{4}\right\}$ \\ Faculty of Law, University of Diponegoro, Indonesia ${ }^{1}$, Faculty of Law, University of Diponegoro, \\ Indonesia ${ }^{2}$, Faculty of Law, University of Diponegoro, Indonesia ${ }^{3}$, Faculty of Law, University of \\ Diponegoro, Indonesia ${ }^{4}$
}

\begin{abstract}
This article aims to analyse the potential use of online dispute resolution (ODR) as an option for dispute resolution in e-commerce transactions. Furthermore, this research will identify the implementation and barriers to use in Indonesia. This research also conducts a comparative study of the practice of implementing ODR in other countries to evaluate legal rules related to dispute resolution so that ODR can be used in Indonesia. The type of research applied in this article is normative juridical. The study results show that the use of ODR is implicitly regulated in several regulations related to Internet and Computer Technology, but there is no comprehensive procedural legal method yet. In practice, the use of ODR has been carried out independently in the regulatory system in e-commerce companies, there is no reason for resolving personal data through ODR. After conducting a comparative study on the application of ODR in the USA and China, this investigation was to revise the law. No.30 of 1999 concerning Arbitration and Alternative Dispute Resolution, the immediate passing of the Law. Protection of personal data and Supreme Court regulations regarding ODR proceedings and ratification of its decisions.
\end{abstract}

Keyword: ODR, Data Privacy, Consumer Protection, E-Commerce

\section{Introduction}

In the industrial era 4.0, the function and role of the internet is not only a means of providing information but has also integrated into the sectors of human life, especially the economy. The digitization of economics brings a major impact on every order of human life. The integration of the internet into the business world has changed the patterns of interaction between economic actors, payment transaction methods, regional coverage, and the transformation of operational management in the business sector ecosystem. The use of digital platforms that can be accessed easily by mobile, has led to significant changes in business activities by taking advantage of efficiency, effectiveness, and mobilization[1]. The kind of feature on a digital economy product that is widely used by the public is e-commerce.

E-commerce is a form of evolution of the conventional trading model that bridges the interaction of parties in a virtual space. The unification of transaction procedures, payments, and delivery procedures are applied in an integrated system on a site/website. The use of the internet network does not require face-to-face contact between sellers and buyers in trade. Signing on the e-commerce platform is done electronically at the time of purchase, checking, and delivery of goods. So that the validity and accuracy of information about consumers and 
sellers is an absolute requirement. In short, the trade transaction pattern has now led to a onestop shopping system, where the transaction agreement includes the agreement for goods/services along with payment and delivery, so that now includes: the flow of information, the flow of money, and the flow of goods[2]. The E-Commerce workflow described above is the same as all processes that occur in conventional trading practices, namely the existence of supply-chain management and distribution of goods and services to consumers, the only difference lies in the operational location.

The potential economic benefits of the e-commerce business in Indonesia are the largest in Southeast Asia. Based on a survey released by Google Temasek in 2019, the gross profit obtained from the e-commerce market reached $\$ 21.0$ billion[3]. In fact, according to a survey released by Mckinsey, the commercial value of the e-commerce industry in Indonesia will almost quadruple or reach a value of US \$ 40 billion in 2022[4]. The data findings are used as a reference for the Government of the Republic of Indonesia to target Indonesia as the main axis of the E-Commerce Industry in Indonesia. Southeast Asia. Positive trends in the E-commerce industry continue in Indonesia. According to the Digital 2020 April Global Shot report at the beginning of 2020, it was noted that the transaction rate in the Business to Consumer (B2C) type of e-commerce transaction reached a value of US \$ 11 billion[5]. The average commodities traded online such as fashion, travel, electronic and beauty products and their transactions are not only domestic but also cross-country. The existence of the COVID 19 outbreak which caused the Government of the Republic of Indonesia to implement a Large-Scale Social Restriction (PSBB) policy and Stay at Home is predicted to increase the use of e-commerce transactions.

The data described above are illustrated that the existence of e-commerce as a digital economy tool has wide influence and attracts public sympathy to use it in trading activities. However, the use of e-commerce has several risks that can cause harm to users. A legal issue that has emerged in the practice of e-commerce is the leakage and misuse of personal data for purposes beyond the scope of the needs of the main business activities in the provider's digital platform. Violation of the misuse of consumer personal data information can occur with two possibilities, namely a third-party breach that hacks the security of the digital e-commerce platform in question and an internal party from an electronic system organizer who acts against the law on consumer data by transferring it to third parties without permission the owner.

Regarding the application for liability to the e-commerce platform, the consumer can file a civil lawsuit based on torts as stipulated in article 1365 of the Civil Code via the court. However, dispute resolution through filing a civil suit to court is considered inefficient. The high cost of the case and the long duration of dispute resolution can cause the plaintiff's expenditure figure to be higher than the loss suffered. With this in mind, the resolution of consumer disputes through court is rarely an option for the community. On the one hand, digital platform companies also have the potential to lose consumer confidence, because the existence of a consumer lawsuit against the company can indirectly create a negative perspective on the company's business.

The scope of e-commerce transactions that are cross-border and without requiring physical meetings between parties is considered to provide significant benefits for the distribution of economic needs, especially during the current COVID 19 pandemics. As a result, the disputants need an alternative resolution of civil in solving cases of abuse of personal data at affordable cost, time efficiency, and without violating health protocols during the COVID 19 pandemic. This study aims to explain the concept and context of Online Dispute Resolution (hereinafter refers as ODR) on various regulatory provisions that exist in Indonesia and at the international level. Furthermore, the researcher will identify the implementation and challenges of ODR in 
the legal system in Indonesia and conduct a comparative study of best practices in other countries to be used as input for the legal framework for using ODR in civil disputes regarding violations of consumer personal data in Indonesia.

\section{Research Methods}

This article applies a normative legal research method. This study uses several approaches used to analyse the role of ODR (online dispute resolution) in bridging civil dispute resolution between consumers and e-commerce platform companies between the conceptual approach, the legal approach, and the comparative approach. The data used in this article is secondary data obtained through a literature study. According to Ronny Hanitijo Soemitro, secondary data in the field of law (seen from its binding strength)[6], are categorized into several legal materials, namely primary legal materials for statutory regulations related to research topics, secondary legal materials namely legal journals and literature books related to ODR, E-Commerce and Personal Data Protection as well as tertiary legal materials namely Black Law dictionaries and Dictionaries. The applied research specification is descriptive-analytical by qualitatively analysing the above legal materials

\section{Result and Discussion}

\subsection{The Legal Overview of the utilization of ODR in Cases of Personal Data Breaches 3.1.1 The Conceptual Overview of Online Dispute Resolution as a part Alternative Dispute Resolution}

The acceleration of digital technology indirectly affects the legal approach, especially in terms of norm-setting, implementation, and dispute resolution. In formal legal practice, the role of Information Communication and Technology (hereinafter refers as ICT) is urgently needed to facilitate and facilitate the resolution of civil disputes, especially in business disputes between business actors and consumers. (Consumers and business actors) that must be considered. One of the dispute resolutions models in legal practice that applies the use of ICT in online dispute resolution (ODR). According to the United Nations Commission on International Trade Law (UNCITRAL) defines ODR as a "mechanism for resolving disputes through the use of electronic communications and other information and communications[7]." Meanwhile, the meaning of ODR according to The Financial Service Authority of The Republic of Indonesia (OJK-RI) is interpreted as an alternative dispute resolution using electronic media and internet networks in the settlement process so that the disputing parties do not need to meet physically[8]. According to Pablo Cortez, ODR is interpreted as a form of ADR which takes advantage of the speed and convenience of the Internet and ICT[9]. ODR is the best (and often the only) option for enhancing the redress of consumer grievances, strengthening their trust in the market, and promoting the sustainable growth of e-commerce. Paying attention to the three meanings shows that the presence of ODR is part of a changing era that requires access assistance from computers and cell phones.

The most important things are needs to be underlined is that ODR is a form of integration of Information Technology with alternative methods of resolving disputes outside the court in general without any physical meeting of the parties. The variety of dispute resolution is the same as alternative dispute resolution which consists of negotiation, mediation, and arbitration[10]. 
The only difference lies in the media/means used, namely the use of the internet as a forum for interaction in the ODR, whereas settlement of disputes outside conventional courts requires the direct presence of the parties. The position of Information Technology is seen as a fourth party which becomes a means of facilitating a meeting of disputants in a virtual meeting.

The use of ODR was initially applied to cybercrime cases such as hacking of personal data and misuse of the content on an internet site. Currently, its use has been utilized and recommended in various private legal disputes such as cases of conventional business disputes, family law issues, and digital domain registration. As is the case with ADR practice, procedures in the ODR mechanism are not binding, meaning that if the settlement of the case does not meet a win-win agreement solution between the two parties, the case can be submitted to the court. The overall procedure for implementing the ODR is carried out in the virtual realm, starting from the initial stage to the end of the application for filing a case, the appointment of a third party as an intermediary, the verification process, the hearing stage (optional), online discussions, decisions and execution of decisions. However, the implementation must still pay attention to the principles of due process of law. In ODR practice, the procedures for controlling and managing information systems are not only carried out by humans but also involve computer software. As it is known, the ODR organizer provides a digital platform that bridges communication between litigants and neutral third parties as intermediaries. The option of using technology facilities in the procedure for implementing ODR indirectly indicates a change in the approach of the parties in interacting, as well as in the dispute resolution process. Examples of informatics technology used by digital platform operators in transmitting proceedings include: teleconferencing, video conference mediation by telephone, and other holographic models.

The overall mechanism for implementing the ODR is carried out in the virtual realm, starting from the initial stage to the end of the case filing, the appointment of a third party as an intermediary, the evidence process, the hearing (optional) stage, online discussions, decisions and execution of decisions. However, the implementation must still pay attention to the principles of due process of law. In ODR practice, the procedures for controlling and managing information systems are not only carried out by humans but also involve computer software. As it is known, the ODR organizer provides a digital platform that bridges communication between litigants and neutral third parties as intermediaries. The option of using technology facilities in the procedure for implementing ODR indirectly indicates a change in the approach of the parties in interacting, as well as in the dispute resolution process. Examples of informatics technology used by digital platform operators in transmitting proceedings include teleconferencing, video conference mediation by telephone, and other holographic models.

The development of innovations in the ICT field has produced several technologies that can be additional options in implementing ODR practice, namely artificial intelligence and algorithms. The use of algorithms is a manifestation of the implantation of technological aspects as a legal entity that emphasizes its function like an expert system whose task is to carry out automatic dispute resolution mechanisms with certain powers such as identifying and offering solutions to disputing parties. Some examples of the use of artificial intelligence in ODR practice are carried out by some platforms include blind negotiation, blind/binding on media and Cybersettle, chargeback by Paypal, or decision making through algorithmic technology[11]. As a breakthrough in dispute resolution practice, the use of ODR applies artificial intelligence technology that is placed as an autonomous party in charge of making case decisions by equalizing its work function like the ability of the human mind. Even though its use contains risks, the results of its use (verdicts) still have to get supervision from humans, especially the assist of experts. 
The online dispute resolution scheme was first initiated at the international level due to concerns about increasing trademark infringement in international business practices. The idea of an ODR system at the international level is called the Uniform Domain Resolution Policy (UDRP). UDRP is a mandatory and binding arbitration system designed to regulate trademark disputes in domain registration[12]. The UDRP system was first adopted and used by a nonprofit organization called the Internet Corporation for Assigned Names and Numbers (ICCAN). The ICCAN position as a non-profit organization is very unique, this is because this institution regulates the majority of internet usage through a control domain name system (DNS) which is cross-jurisdictional. Then the UDRP scheme was recommended by WIPO (World Intellectual Property Organization) and received a positive response from the business world. The ODR model framework offered by UDRP illustrates the arrangement of digital business practices interaction with third parties by registering a domain name at the beginning of the contract.

Based on the perspectives of operators, ODR practices qualify into two types, namely online private platforms and online platforms managed by public agencies. The main thing that distinguishes the two is that the private ODR platform is part of the company's digital product service system which is based on business goals (profit-oriented) by promoting the novelty of innovation in serving market needs. Meanwhile, digital platforms managed by public bodies are usually funded by the government budget, non-commercial, and supported by judicial means. On the private ODR platform, it is grouped into two types, namely self-contained and full service[13]. Self-contained ODR platforms are designed to resolve internal disputes between users, for example, online marketplaces like e-bay, amazon, etc. In a self-contained marketplace, the provider sets service standards and agreements for the account holders (sellers and buyers) that accommodate the rules of the game in transactions. The operational standards in the marketplace are determined by the organizers in particular, such as the imposition of sanctions for violations, payment delays, refunds of fees, account blocking and suspensions, user rating assessments, and publication of feedback. Meanwhile, the full-service platform tends to be more open to anyone in dispute by providing an option for determining ODR according to the type of dispute (case, court fee, and other factors). Modria is an example of a cloud computing-based platform designed to resolve various types of disputes and their levels, both by the private sector and the government.

The contrast to the public ODR platform owned by Government Agencies and public organizations that implement the ODR system as an alternative form or complementary element in judicial procedures in conventional disputes. Several countries have institutionalized the concept of public-type ODR, among others, the United States, Mexico, and Canada which are commonly used to facilitate business disputes over claims for losses by consumers against business actors. The scope of public ODR jurisdiction can include cross-territoriality between countries. As in European Union countries that have 75 ADR schemes, to build an integrated general framework the European Parliament and the Council of the European Union adopted the Consumer ADR Directive and the Regulation on consumer ODR. Domestic ADR regulations in EU countries continue to apply based on the "Common Minimum Quality Principles". This is supported by the provision of a free ODR platform in all regions of the European Union member states.

\subsubsection{The Indonesian ICT Regulations and International Arrangement Perspectives on Privacy Data Towards the Use of Online Dispute Resolution}

The concept of Online Dispute Resolution has been internalized into several national regulations both at the legal and regulatory levels of technical institutions. Modernization in the 
economic sector adapted and combined with information technology, especially in the trade sector, has encouraged the state to provide guarantees of protection against the emergence of new legal disputes rooted in conflicts of interest. In-Law. No.7 of 2014 concerning Trade, the use of online dispute resolution is implicitly regulated as one of the options for dispute resolution in e-commerce business activities between business people and consumers. As regulated in the provisions of Article 65 paragraph (5) which states that:

"In the event of a dispute relating to commercial transactions through electronic systems, people or entities who have disputes can resolve the dispute through the courts or through other dispute resolution mechanisms."

Paying attention to the provisions of this article, it can be stated that the Trade Law provides freedom for parties to disputes on e-commerce to determine settlement institutions both through the court and outside the court. So that these provisions can be used as a basis in choosing online dispute resolutions in Indonesia.

Meanwhile, the online dispute resolution arrangement in the Law. No.11 of 2008 concerning Electronic Information and Transactions (hereinafter referred to as the Information and Electronic Transaction Law) which is based on making electronic contracts designed and agreed upon by business actors and consumers on a digital platform. In the electronic contract, the consumer and business actor determine the method of dispute resolution that has the potential to arise from the holding of the relevant electronic business transaction. Settlement can be through court forums or alternative dispute resolution institutions that have the authority to handle disputes arising from the transaction. However, if the disputants do not specify a dispute resolution institution to resolve conflicts that have the potential to arise in e-commerce transactions, then the principles of international law apply. The confirmation of the potential use of online dispute resolution is regulated in the provisions of article 38 paragraph (2) which states that:

"The society under provisions of Rules may bring class-action lawsuits against parties that provide Electronic Systems and/or using Information Technology to the society loss, under Rules".

The context of law enforcement which aims to obtain peace and public order referred to above is that the state provides opportunities for the public as consumers to file lawsuits when violations occur due to electronic transaction activities. The public is also encouraged to play an active role in the scope of business activities related to digital systems such as e-commerce, e-contracts, e payments, and business service models in other electronic platforms. The essence of the above provision implies that there is sufficient opportunity to take advantage of ODR in resolving business disputes on the internet network, as long as the method is intended as a means of law enforcement. This is then emphasized in the provisions of article 18 of the Information and Electronic Transaction Law which states that the disputants are also given the authority to determine legal choices that apply to cross-country electronic transactions, so that dispute resolution via ODR can be the right means without worrying about differences in geographical boundaries. The proposal to use ODR is usually included in the agreement clause between the disputants in an electronic contract which is based on the principle of freedom of contract. This shows that the regulation in this law frees the parties to determine the choice of dispute resolution forum institutions and legal choices.

The Settlement of personal data disputes are not clearly regulated in the Information and Electronics Law and its amendments, but is regulated quite specifically in the Regulation of the Minister of Communication and Information Technology No.20 of 2016 concerning Protection of Personal Data in Electronic Systems. Article 26 states that each owner of personal data and the Operator of electronic systems can file complaints to resolve disputes on personal data to the Minister of Communication and Information Technology regarding the occurrence of 
misuse and failure of personal data protection. The complaint mechanism is intended as an effort to resolve civil disputes through deliberation or other alternative dispute resolution. However, the difference lies in the involvement of the Government in forming a panel to decide dispute resolution cases. Complaints can be made based on a non-written notification of the failure of the protection of personal data by the e-commerce platform operator, either that has the potential to harm or not to the consumer. Complaints can be made no later than 30 days after the complainant finds out about information on the violation of his personal data on the relevant digital platform. However, the use of ODR has not been clearly defined in this regulation.

Law No.30 /1999 regarding Arbitration and alternative dispute resolution (hereinafter referred to as Arbitration and alternative dispute resolution Act) is provided legal opportunities to determine ODR as an alternative dispute resolution option. In Article 1 point 10 it is stated that the methods of dispute resolution outside the court include consultation, negotiation, mediation, conciliation, expert judgment, arbitration. This provision reflects that this law encourages out-of-court dispute resolution methods using technology under the times. However, the Arbitration and Dispute Resolution Law does not describe in detail the form of the institution, its duties, and powers. Rather, it only regulates the competencies and procedures that apply. Likewise, in the case of the selection of laws used, this law leaves entirely to the disputants. if the disputants do not make a choice of law and or there is a disagreement on this matter, then the determination of law and dispute settlement forums shall be based on the principles inside Private International Law.

Opportunities for choosing ODR in resolving disputes over personal data breaches are also implicitly regulated in the law. No.14 of 2008 concerning The Transparency of Public Information as described in Article 1 points 6 and 7 which state that the settlement of public information disputes between parties can be carried out through adjudication and mediation forums. Even though until now the Government of the Republic of Indonesia has yet to issue specific arrangements regarding personal data, however, in article 56 of the Personal Data Protection Bill which is currently being discussed in the National Legislation Program, forums for resolving disputes over personal data breaches are left to the disputants who may choose to use alternative dispute resolution or litigation channels. The procedural law that is applied refers to the provisions of the Procedural Law on litigation settlement (HIR and RbG) and / or the proceeding mechanism that applies to ADR. However, the terms of use and settlement of ODR are not explicitly discussed.

At the regional level, the application of the ODR system was proposed at the ASEAN Economic Community Development forum in 2008. ODR was included in the plan included in one of the blueprints which were then followed up to be included in The ASEAN Committee on Consumer Protection. Strengthening the ODR system which refers to the standard of the Civil International Law system is the focus of the agenda in regulating E-Commerce transactions across ASEAN member countries. ODR arrangements are also discussed again to be formulated at the ASAPCP (The ASEAN Strategic Action Plan for Consumer Protection for the period 2016-2025. The steps taken include: establishing a national scale ODR system for each ASEAN member, establishing a regional ODR network at the ASEAN level. as well as establishing a complaint mechanism and cross-country investigation at the ASEAN regional scale Follow up on the three strategic pillars above by forming the ASEAN Coordinating Committee on Electronic Commerce.

\subsection{Legal Challenges on the implementation of ODR in Indonesia to Bridging Privacy Data Settlement}

\subsubsection{The Implementation of ODR for E-Commerce Dispute Settlement in Indonesia}


As known, the ODR mechanism in national law to deal with personal data breaches does not yet have a clear and detailed conceptual formula. However, in broad outline, in practice, the legal subjects involved in the use of ODR qualify into three parties, namely first, the service users. Service users on the ODR platform in civil and business cases are parties to the dispute. Disputing parties consist of consumers (application users, both buyers, and sellers) who feel their rights have been harmed and digital application organizers who are suspected of violating or abusing their authority which has implications for consumer rights. The second party that plays a role is the provider and operator of the ODR service as the facilitator of dispute resolution. ODR service providers can be carried out by private and government parties.

According to Joseph W. Goodman, three ODR models are widely applied by the international community, namely fully automated cyber, using software and facilitators, and using online technology[14]. In the fully automated cyber model, dispute resolution is carried out by a software system that has the role of automatically bringing together the reporting party and the reported party until an agreement is reached. Meanwhile, the using software and facilitator model consists of several stages, among others, first, the appointment of a third party as a facilitator who acts as an intermediary for the disputing parties to provide suggestions on the appropriate negotiation model and compile the demands submitted in the ODR process. The presence of arbitrators or third-parties as facilitators of dispute resolution remains an important key and cannot be directly replaced by technological tools. Then the software on the ODR platform will identify the parties' demands to find a solution. The using online technology approach applies several service features in the form of email, video conferences, chat rooms, and instant messaging. The concept of using online technology usually uses three ways of settlement, namely negotiation, arbitration, and mediation.

Referring to legal norms in the Arbitration and Alternative dispute resolution Act as the initial basis for enabling the application of ODR in non-litigation practices, the concept of using online technology is the closest scheme to the provisions of this regulation. This can be used as an option for resolving civil disputes over the abuse of consumer personal data by e-commerce platforms. In the using online technology system, it usually begins with a report on claims for losses by consumers whose privacy rights are violated by the e-commerce platform company as the reported party. The application is submitted to the ODR service provider institution. Then the ODR organizer will send a notification via email to the reported party, namely the digital platform service provider company for the demands submitted by the consumer.

Furthermore, the e-commerce platform company as the reported party will accept the dispute resolution offer and provide a description of the intended final result and propose a thirdparty election as a facilitator. Responding to this, the ODR platform operator will forward the reported request for the appointment of a facilitator who will be asked for approval or rejection from the consumer. If the reporting party agrees, the request will be forwarded to the facilitator. The facilitator is obliged to review the request for a resolution that is expected by each party to find an ideal middle way for the disputing parties. The role of the facilitator participates in bridging the parties to negotiate with each other to find common ground for dispute resolution. If the reporting party and the reported party reach an agreement, the ODR organizer will announce the result of the decision for the disputing parties. The binding power of the ODR organizer's decision is largely determined by the variant of the mechanism chosen by the parties. If the ODR decision which is the result of the negotiation and mediation method is generally not legally binding. Whereas ODR decisions using the arbitration model can be legally binding, however, the execution of these decisions must take court routes first. However, if the agreement of the disputing parties fails to materialize, the parties can file a lawsuit again or continue the dispute settlement through litigation. 
In the practice of handling consumer service complaints in Indonesia, the public is given various options in terms of sectoral dispute resolution forums among government agencies[15]. Consumers are required to identify in advance cases of violation of their rights before determining which institutions can be visited to submit a complaint. This causes the public as consumers to be reluctant to file complaints about dispute resolution outside the court. In response to this, the Ministry of Trade of the Republic of Indonesia established a digital platform to serve complaints of consumer violations including in cases of e-commerce transactions to resolve disputes outside the court via digital applications. Based on data compiled by the Ministry of Trade, the number of registered complaints reached 1771 cases registered on the platform[16]. However, this program only lasted a year due to weak coordination between government agencies regarding server management and the authority to administer cases.

The Settlement of disputes over violations of consumer personal data through ODR is also carried out internally (self-regulation) by electronic system administrators. The media used is on a server belonging to an e-commerce platform company. This is what is practiced on several websites of e-commerce marketplace companies in Indonesia such as Tokopedia[17]. The digital platform owned by Tokopedia provides a privacy policy and terms and conditions for users to resolve business disputes between sellers - buyers and marketplace organizing companies. The terms and conditions that are regulated digitally include several things including the choice of law that will be used to resolve disputes on the application server of an e-commerce company. However, the legal jurisdiction used is limited to the laws applicable in the territory of Indonesia, so it is difficult to apply for e-commerce transactions that occur across countries.

The use of ODR is limited to the banking sector through alternative dispute resolution institutions, where it functions as a support in supporting data documentation, correspondence, and possible communication by using e-mails related to sending letters from the LAPSPI secretariat (Indonesian Banking Dispute Resolution Alternative Institute) to disputants. The regulation on the use of information technology in the settlement of banking disputes by LAPSPI has been regulated for the type of adjudication (LAPSPI Regulation No.8 / LAPSPIPER / 2015) and mediation (LAPSPI Regulation No.7 / LAPSPI-PER / 2015), but the arbitration mechanism has not stipulated provisions.

\subsubsection{The Legal Obstacle on Applying ODR for Privacy Data Breach in Indonesia}

ODR is one of the dispute resolutions options that has many advantages in terms of cost, efficient dispute resolution time, and well documentation of proceedings in a virtual system. The effectiveness of regulation is strongly influenced by the factors contained in several interrelated elements called the legal system. According to Lawrence M. Friedman, a good legal system is strongly influenced by three main components, namely legal substance, legal structure, and legal culture[18].

Based on the legal substance aspect, the use of ODR in resolving civil disputes on violations of consumer personal data in electronic transactions on the platform does not yet have legal rules that regulate both material and procedural aspects. As a country that adheres to negative law principles, the use of ODR cannot be implemented effectively and comprehensively in Indonesia because no written rule specifically accommodates it. As it is known, the substance of legal rules that are material in nature is Law. Protection of Personal Data which serves as the main regulation to become the main material legal product in dealing with violations and or misuse of personal data is still in the National Legislation Program stage which is still being discussed jointly between the House of Representatives and the Government. As a result, this bill has not been able to be promulgated to the public as a legal umbrella for the use of ODR to handle cases of personal data protection. This condition causes legal certainty over the use of ODR to be biased because disputants can have doubts about the benefits of 
dispute resolution with this model and tend to use litigation resolution which is less effective for business practice.

Meanwhile, from the procedural side, there is a legal vacuum that regulates the method of implementing procedural practices through ODR related to the selection of digital applications, procedural mechanisms, and security of the platforms operated by the organizing institution. The preparation of standard legal procedures for the implementation of ODR is an issue that must be considered very seriously for the organizers. As is well known, the use of ODR connected to the ICT system is very vulnerable to security for the confidentiality/privacy of disputants, impersonal problems, and literacy in the use of digital devices as an ODR platform. Security aspects of confidentiality and privacy protection of disputants, including all kinds of recorded conversation documentation, must be guaranteed by restrictive arrangements regarding access restrictions for parties outside of disputants and prohibitions for one or all of the disputants to disseminate the contents of the proceedings without the permission of the organizer. This issue is a crucial issue considering that initially ODR will be used to resolve personal data problems in a civil manner, however, it creates a new problem in the form of a violation of the privacy data of disputants.

The second weakness of the substance aspect of procedural law is the execution of decisions. As it is known, the types of dispute resolution in ODR vary the same as ADR practice, only the facilities and locations are distinguished. The execution of civil decisions has an unfavorable record, even though it has permanent legal force (In Kracht)[19]. As it is known, one of the ODR models used by e-commerce platform companies, namely internal online settlement between business actors, providers, and consumers, the validity of the decision is still questionable. So that it can cause difficulties in the execution. This problem becomes a serious challenge for the implementation of the binding power of the ODR decision which is very dependent on the variant determined and agreed upon by the disputants.

The role of an institution plays an important position in case handling. In practice, ODR can be carried out by various institutions, both from private and government associations (Independent Alternative Disputes Settlement Bodies in the field of financial services) (National Arbitration Board and Consumer Settlement Agency) depending on the choice and agreement of the disputants. The diversity of institutions administering the ODR has the potential to cause differences in decisions taken by each forum or institution, resulting in a loss of legal certainty in the same case. In the settlement of personal data disputes as stipulated in the Regulation of the Minister of Communication No.20 of 2016 concerning Personal Data Protection in Electronic Systems, where the procedure requires the presence of the Government as a case breaker outside the court. Concerning institutions that have the authority to handle this case, an independent institution that is given a special mandate is needed to achieve transparency and neutrality. Meanwhile, the Personal Data Protection Bill has not formulated the subject of the regulator and organizer of dispute resolution, because there is no formulation agreed upon by the Government and the DPR regarding the institutional concept, namely forming a new independent institution or expanding the existing institutional authority structures in the country.

Besides, the challenge of legal literacy in the use of technology for disputing parties and administrators of the ODR system is a challenge in terms of legal culture. In the aspect of procedural law, the legality of regulating the procedures for implementing ODR that has not been accommodated in detail creates doubts for the public, especially regarding the viewpoint of the legality of the use of electronic documents as evidence. Certainty in the use of electronic signatures has also not received certainty in the arrangements in the Arbitration Law and alternative Dispute Resolution. Also, for legal practitioners, the use of ODR has difficulty 
predicting the psychological condition of the disputing parties because they do not make direct face-to-face contact.

\subsection{The Framework of Legal Arrangements for The Use of ODR in cases of personal data breaches in Indonesia}

\subsubsection{Best practices for using ODR in overcoming personal data breaches on the E- Commerce platform}

To design a more efficient, effective, and easy accessibility cross-border dispute resolution, the majority of countries in the world have launched alternative means of dispute resolution by utilizing information technology or what is popularly known as Online Dispute Resolution (ODR). The use of ODR as a media for dispute resolution has been widely applied in several countries in the world such as the United States and China.

\subsubsection{Online Dispute Resolution Practice in the United States}

The ODR model applied in the United States consists of two types, namely a selfregulation system and using the facilitation of an arbitration institution. The use of ODR with a self-regulation model was first used by The National Center for Automated Information Research in Philadelphia, the USA in 1995. This institution creates a virtual platform as ODR media with the name Virtual Magistrate which functions to resolve disputes between electronic system administrators and users. Four years later, E Bay in collaboration with the University of Massachusetts established a digital platform called SquareTrade to facilitate mediation between sellers and buyers in e-commerce transactions. Another example of a marketplace platform that carries out ODR self-regulation is Modria. Modria is the most successful ODR Platform with a total of 100,000 case requests received per year[20]. There are two types of online dispute resolution implemented by Modria, namely online mediation, and arbitration.

Whereas ODR applications through traditional institutions in America are carried out by the American Arbitration Association (hereinafter referred to as AAA). The formation of the AAA is defined in the Federal Regulations on Arbitration Act. AAA is an institution that handles disputes that are not limited to business cases such as intellectual property rights, technology, consumers, financial services, international business matters, and construction. The methods used by AAA are mediation, arbitration, court, and online settlement. The procedure for implementing the ODR applied by the AAA consists of several stages. The initial stage is the registration of disputants on a Webfile that is managed by the institution, which is followed up by filling out an online form by the disputants. After registering, disputants can submit claims online to AAA via email or other online devices. The plaintiff can add a page to upload documents related to the dispute including filling out the desired demands against the defendant. After filling out the form and declaring it complete, the AAA Party will announce the third party who will be the panellist in the case. The procedure for the proceedings will be announced by the AAA Party online to the disputants.

\subsubsection{Online Dispute Resolution in the People's Republic of China}

ODR regulations in China are not regulated in the Special Law but are implicitly regulated in article 16 of the Arbitration Law of the People's Republic of China. In Article 16 it is stated that the arbitration agreement must include an arbitration clause stipulated in the contract as well as an agreement for submission of dispute resolution to arbitration concluded in other written forms before or after the dispute arises.

The mechanism for implementing ODR in resolving e-commerce business disputes in China is under the supervision of the China International Economic and Trade Arbitration Commission (CIETAC) which is self-regulated into a Code of Conduct, namely CIETAC Online Arbitration Rules. CIETAC formed a special agency that handles ODR through a website 
that was created to serve as a platform for proceedings to resolve business and consumer disputes. The dispute resolution method applied by CIETAC uses online arbitration and mediation channels. However, it is possible to comply with the provisions in Article 15 of the Arbitration Law of the People's Republic of China which allows the administration of arbitration to be combined with the implementation of reconciliation based on the consent of the disputants.

In brief, the procedural mechanism in arbitration practice held at CIETAC consists of several stages, including the First Phase, which is the beginning of the procedure for filing a case[21]. At this stage, the disputants submit a case request and a statement and proof of evidence from each party. The second phase is the security and confidentiality arrangements in the online arbitration process, which are then followed up by hearings from the parties. The arbitrators appointed by CIETAC have the authority to terminate the reconciliation process if it does not bring conciliation to the disputants or is at the disputants' request. The failure of the reconciliation process will continue at the arbitration stage.

\subsubsection{Urgency to Evaluate the Regulations to Operate ODR Effectively Against Personal Data Breach}

The presence of law in society functions as a tool for social engineering to create order and order by harmonizing various interests so that there is no conflict between stakeholders. The emergence of ODR as a method of dispute resolution in the e-commerce business sector is the answer needed by business actors and consumers to obtain a case settlement that is fast, effective, and cost-efficient. To accommodate the existence of ODR, a legal instrument that is responsive to the needs of the community is needed. Based on the description of the obstacles to implementing and regulating ODR as stated in the above discussion sub-chapter, the Indonesian Government must evaluate legal policies by making corrections and redesigning regulatory models in the procedural law sector, the Personal Data Protection Law, and delegating agencies that have the authority to implement them.

Procedural legal provisions in the law. Arbitration and alternative dispute resolution are still relevant to be used as a basis for using ODR in resolving disputes between e-commerce platform organizers and consumer users. However, there needs to be updates and adjustments to the substance in it with the ODR concept, including First, the arrangement of the proceeding mechanism in the ODR system network which includes the choice of the ADR model, procedures and requirements for registering reports, procedures for calling the parties by the organizer, the deliberation/mediation/adjudication process. / arbitration, decision making, and execution. The focus of the second revised procedural law policy on the Arbitration Law and Alternative dispute resolution is the Regulations for Standardization of the Operational System and the protection of data system security in applications used in ODR. ADR operators are required to follow and adopt the provisions of the ICT Law, Government Regulation no. 71 of 2019 concerning the Implementation of Electronic Systems and Transactions concerning the Ministry of Communication and Informatics Regulation No.19 of 2016 concerning Personal Data Security and the Personal Data Protection Law (if it has been passed by the Government). The third is the arrangement of features used such as video, chat, simultaneous combination via documents (google document edited remotely), e-mail, and virtual meeting/discussion platform forums.

The urgency for the drafting and issuance of laws. Personal data is a very vital legal instrument in terms of data collection and management. This is apart from the mass collection of data by the Government or the private sector with or without the knowledge of the private sector. The need for a Law on Personal Data as the main regulation cannot be separated from the overlap of the substance of the 32 laws. Other sectoral roles that partially regulate personal data. Forms of disharmony include the purpose of processing personal data, notification, or 
approval from the owner of the personal data, the retention period for personal data. Then, the destruction, deletion, or alteration of personal data. This asynchrony is a loss for the community so that to support the implementation of ODR, the presence of this law is very urgent to be issued by the Government.

Institutions are the keys that play an important role in the legal system. The self-regulation type ODR model that has been implemented by several e-commerce companies should be maintained, but with several regulatory developments. The regulation and implementation of the ODR Informatics system in the e-commerce platform conform to the standards used by the International Council for Online Dispute Resolution. Apart from the fact that the legal issue discussed in this article is the violation of personal data, the institution that is given the authority is an independent body established and appointed by the Government to handle and implement the ODR mechanism in cases of misuse of personal data.

The presence of information technology has had a major influence on how disputes are resolved in the business sector, this phenomenon also spreads to its regulatory patterns to bridge the legal needs of society through regulation by harmonizing the development of knowledge and technology. The process of drafting a law takes a long time, so it is quite difficult to remain in a single phase in line with the evolution of technological advances that continue to move rapidly. This contrasting condition has implications for the legal certainty that disputants get because there is no clear corridor regarding the boundaries of rights and responsibilities which cannot be predicted. This description of the legal situation is not new, because the law is said to be always one step late from the social dynamics of society.

E-commerce transaction areas that are full of digital space require a separate dispute resolution arrangement (sui generis). Regulations that are too rigid will create obstacles to advances in the world of technology and economy and block the positive benefits that can be obtained from the use of ODR. As described in the discussion above, in practice the use of ODR has been carried out by national e-commerce platform companies and Alternative Dispute Resolution Agencies in the financial sector by emphasizing self-regulation. Therefore, this practice is still allowed to be operationalized by observing the principles in several alternative traditional dispute resolution models.

Responding to this issue, the article offers three legal solutions that can reduce risk and bridge the use of ODR in Indonesia, namely the first revision of the Law. Arbitration and dispute resolution alternatives (Long-term advice). This proposal is a critical point that must be carried out by the Government of the Republic of Indonesia in facing Industry 4.0. The submission of revision of the Law Arbitration and alternative dispute resolution is very difficult to do soon, although the legal issue of ODR procedure formulation is very urgent. This is because the mechanism takes a long time from the stage of making an academic paper to its enactment. However, it must be included in the long-term plan for the development of the National Procedural Law. The second legal solution is that in the short term it is best for interested institutions and e-commerce companies to determine operational standards in cases of personal data breaches through ODR. Of course, by continuing to review and pay attention to harmonization with other related laws. Third, concerning the legality of ratifying the ODR decision in cases of violation of personal data so that execution can be carried out, the administering institution (a special institution established by the Government of the Republic of Indonesia) can file registration for the decision through the District Court. The registration procedure for ODR decisions requires legal support from the competent institution, namely the issuance of a Supreme Court decree. 


\section{Conclusion}

The design of Regulations regarding ODR has been formulated lex generalis on partial of regulations in Indonesia so that there is already a legal basis that can cover the use of ODR in Indonesia. Even the legal basis for the use of ODR has also been accommodated implicitly in several regulations for the Alternative Dispute Resolution Institutions partially. However, implementing ODR in Indonesia requires a more specific legal instrument arrangement both in terms of material law and procedural legal instruments. The two provisions of this regulation should be considered so that ODR can provide legal certainty, justice for the disputing parties, and benefits for the existence of ODR as an instrument for resolving disputes over the abuse of consumer personal data in e-commerce business practices. The author recommends several legal solutions in the long and short term that can be useful to cover weaknesses in the use of ODR in Indonesia, including First, revising the Law on Arbitration and Alternative dispute resolution. Second, accelerate the ratification of the Personal Data Protection Bill and the appointment of authorized agencies. Third, the regulation on the ratification of the issuance of procedural standards in the ODR and ratification of the decision through a Supreme Court Regulation, but with due observance of the alignment of the regulations with other related laws.

\section{Acknowledgment}

Acknowledgment.The authors would like to appreciate and thanks to Faculty of Law Diponegoro Semarang for the support for us on funding and moral aspects. Other thanks to the committee of ICETLAWBE 2020 for giving a review, suggest and accept this paper to present 11 in this annual scientific event. Then, we would like to thank The Financial Service Authority of The Republic of Indonesia who is share important data that was used by the authors as references contents that support for analysis and developing an idea on this research article. As the result, this study is high- qualification substances and proper to be published. the authors wish this article can provide contributions for scholars and practitioners in the field of law.

\section{References}

[1] I. Lukito, "Tantangan Hukum dan Peran Pemerintah dalam Pembangunan E-Commerce (Legal Challenges and Government'S Role in E-Commerce Development)," J. Ilm. Kebijak. Huk., vol. 11, no. 3, 2017.

[2] E. Makarim, "Kerangka Kebijakan Dan Reformasi Hukum Untuk Kelancaran Perdagangan Secara Elektronik (E-Commerce) Di Indonesia," J. Huk. Pembang., vol. 44, no. 3, p. 314, Sep. 2014, doi: 10.21143/jhp.vol44.no3.25.

[3] Google, Temasek, and B. \& Company, "e-Conomy SEA 2019 Report Swipe Up and to the right: Southeast Asia $\$ 100 \quad$ bilion Internet economy," 2019. [Online]. Available: https://www.bain.com/globalassets/noindex/2019/google_temasek_bain_e_conomy_sea_2019_report.pdf.

[4] K. Das, T. Tamhane, B. Vatterott, P. Wibowo, and S. Wintels, "The digital archipelago: How online commerce is driving Indonesia's economic development," McKinsey Co., no. August, pp. 1-72, 2018, [Online]. Available: www.mckinsey.com/featured-insights/asia-pacific/the-digital-archipelago-how-online-.

[5] S. Kemp, "Digital 2020: April Global Statshot," 23 April, 2020. https://datareportal.com/reports/digital-2020april-global-statshot.

[6] R. H. Sumitro, Metodologi Penelitian Hukum dan Jurimetri, 5th ed. Jakarta: Ghalia Indonesia, 1994.

[7] United Nations Commission on International Trade Law, "UNCITRAL Technical Notes on Online Dispute 
Resolution." Vienna, $\quad$ pp. $\quad 1-9, \quad$ 2017, $\quad$ Online]. https://www.uncitral.org/pdf/english/texts/odr/V1700382_English_Technical_Notes_on_ODR.pdf.

[8] D. P. O. J. Keuangan, Kajian Perlindungan Konsumen Sektor Jasa Keuangan: Online Dispute Resolution (ODR). Jakarta: Departemen Perlindungan Konsumen OJK, 2017.

[9] P. Cortés, "Developing online dispute resolution for consumers in the EU: A proposal for the regulation of accredited providers," Int. J. Law Inf. Technol., vol. 19, no. 1, pp. 1-28, 2011, doi: 10.1093/ijlit/eaq011.

[10] I. M. Widnyana, Alternatif Penyelesaian Sengketa \& Arbitrase. Jakarta: Fikahati Aneska, 2014.

[11] M. S. A. Wahab, E. Katsh, and D. Rainey, Online Dispute Resolution Theory and Practice: a Treaties on Technology and Dispute Resolution. The Hague: Eleven International Publishing, 2012.

[12] M. G. Bowers, "Implementing an online dispute resolution scheme: Using domain name registration contracts to create a workable framework," Vanderbilt Law Rev., vol. 64, no. 4, pp. 1265-1309, 2011.

[13] A. H. Raymond and S. J. Shackelford, "Technology Ethics and Access to Justice- Should an Alogrithm be," Michigan J. Int. Law, vol. 35, no. 3, pp. 485-524, 2014, [Online]. Available: http://www.mjilonline.org/wordpress/wp-content/uploads/2015/04/35-3_Technology-Ethics-and-Access-toJustice-Should-an-Alogrithm-be.pdf.

[14] J. W. Goodman, "The Pros and Cons of Online Dispute Resolution: An Assesment of Cyver-Mediation Websites," Duke Law Technol. Rev., vol. 2, no. 1, pp. 1-16, 2003, [Online]. Available: https://scholarship.law.duke.edu/dltr/vol2/iss1/2.

[15] I. Aprilianti, "Policy Paper No. 27 Protecting People: Promoting Digital Consumer Rights," no. 27. Center for Indonesian Policy Studies, Jakarta, pp. 1-46, 2020, [Online]. Available: https://repository.cipsindonesia.org/media/310045-melindungi-masyarakat-memajukan-hak-hak-83b832fd.pdf.

[16] United Nations Conference on Trade and Development, Voluntary Peer Review of Consumer Protection Law and Policy: Indonesia. Geneva: United Nations Conference on Trade and Development, 2019.

[17] Tokopedia, "Tokopedia Terms \& Condition," April, 2, 2020. https://www.tokopedia.com/terms

[18] L. M. Friedman, The Legal System: A Social Science Perspective, VI. Bandung: Nusa Media, 2018.

[19] A. Jebabun et al., "Initial Assessment Problems of Court Decision Enforcement System in Indonesia," Jakarta, 2018. [Online]. Available: https://leip.or.id/wp-content/uploads/2018/10/LeIP_Asesmen-Awal-EksekusiPutusan-Perdata.pdf.

[20] K. Mania, "Online dispute resolution: The future of justice," Int. Comp. Jurisprud., vol. 1, no. 1, pp. 76-86, 2015, doi: 10.1016/j.icj.2015.10.006.

[21] Q. He, "Legal Issues and Challenges of ODR: A Chinese Perspective," 2012. http://uncitralrcap.org/wpcontent/uploads/2015/11/Day2_Panel2_B_1_Qi_Sheung_Legal-Issue-and-Challengesof-ODR.pdf. 